\title{
BENANG MERAH FILSAFAT INDIA \\ DENGAN TEOLOGI HINDU NUSANTARA PADA AJARAN \\ MIMAMSA DAN YOGA DARSANA DALAM TEKS SIWA DHARMA
}

Oleh :

I Gede Arum Gunawan, S.Ag.

\begin{abstract}
ABSTRAK
Agama Hindu memiliki kontruksi ajaran agama yang lengkap, yakni Tattwa (teologi, filsafat keagamaan), Susila (etika), dan Acara (ritual). Ketiga hal tersebut menjadi satu kesatuan yang tak dapat dipisahkan. Salah satu teks keagamaan Hindu Nusantara yang menunjukkan keterkaitan ketiga konstruksi/ kerangka ajaran Hindu tersebut adalah Lontar Siwa Dharma. Dalam teks Siwa Dharma dibahas mengenai penjabaran konsep teologi Siwa Sidhanta yang diejawantahkan dalam perbuatan sebagaimana dijabarkan dalam konsep Tri Kaya Parisudha dalam teks ini. Serta pembahasan mengenai konsep Panca Yajña dan berbagai tujuan spiritual yang terkandung dalam yajña tersebut.

Sebagai sebuah teks keagamaan yang tergolong kitab Agama dalam kodifikasi Weda, Teks Siwa Dharma memiliki hubungan yang amat erat dengan ajaran Darsana, sebagai sebuah bangun ilmu filsafat keagamaan Hindu. Teks ini mampu menunjukkan hubungan erat antara ajaran Darsana dengan konsep pemikiran Hindu Nusantara. Teks ini menunjukkan bagaimana landasan filosofis Darsana diterjemahkan dalam gerak perilku umat Hindu Nusantara. Ajaran Teologi Hindu Nusantara ini amat sejalan dengan ideologi dan praktek-praktek ajaran Darsana khususnya Mimasa dan Yoga Darsana.
\end{abstract}

Kata kunci: Teologi, Mimamsa Darsana, Yajña, Yoga Darsana

\section{ABSTRACT}

Hinduism has a complete construction of religious teachings, namely: Tattwa (theology, religious philosophy), Susila (ethics), dan Acara (ritual). These three frameworks are an inseparable unity. One of the religious texts of Hindu Nusantara which shows the interrelation of these three Hinduism frameworks is Siwa Dharma manuscript. In the Siwa Dharma text, it is discussed about the elaboration of the theological concept of Siwa Sidhanta which is embodied in 
actions as outlined in the concept of Tri Kaya Parisudha in this text. It is also discussed about the concept of Panca Yajña as well as the various spiritual goals which are contained in those yajña.

As a religious text which belongs to the book of Agama in the codification of Vedas, Siwa Dharma text has a very close relationship with the teachings of Darsana as a form of Hindu religious philosophy. This text is capable of showing the close relationship between the teachings of Darsana with the thinking concept of Hindu Nusantara. This text shows how the philosophical foundation of Darsana is translated into actions and deeds of Hindu Nusantara people. This teaching of Hindu Nusantara theology is very much in line with the ideology and practices of the teaching of Darsana especially Mimasa and Yoga Darsana.

\section{Keywords: Theology, Mimamsa Darsana, Yajña, Yoga Darsana}

\section{Pendahuluan}

Agama Hindu pada awalnya disebut dengan Sanatana Dharma, yang secara kontekstual dapat dimaknai sebagai agama yang kekal abadi. Dikatakan sebagai agama yang kekal abadi karena keberadaan Agama Hindu sebagai agama kuno, hingga saat ini masih bisa tetap eksis bahkan semakin berkembang pesat. Hal itu menandakan ajaran-ajaran dalam agama Hindu masih relevan dengan kondisi masyarakat di masa sekarang ini. Relevansi ajaran tersebut tentunya karena sifat fleksibelitas dan universalitas ajaran Agama Hindu, yang menerima keragaman budaya dan pola perilaku umatnya dengan menjiwainya dan membuatnya lebih hidup.

Agama Hindu bukanlah agama yang dogmatik dan apologetik, melainkan Agama Hindu adalah agama yang scientific dan demokratis (Donder, 2010: 87). Hal ini dikarenakan Hindu bukan agama yang kaku, dengan mengurung umatnya dengan sekadar mengimani ajarannya semata. Mengurung umatnya untuk meyakini dan mencari pembenaran untuk membenarkan semua sabda-sabda Tuhan dalam kitab suci. Akan tetapi, Agama Hindu membuka diri kepada umatnya untuk mendalami segala ajaran yang terkandung di dalamnya dengan menggali dan memahaminya lebih dalam, Agama Hindu membenarkan umatnya untuk mengkritik dan mencari hakikat kebenaran Weda itu dengan berbagai macam cara, seperti yang dinyatakan dalam kitab Brahma Sutra I.1.1 yang berbunyi; Athāto brahmajijñ̄āsā, yang terjemahannya "sekarang karena itulah penyelidikan tentang Brahman harus dilakukan" (Vireśvarānanda, 2004: 68). Berdasarkan petikan sutra tersebut maka untuk memahami kesejatian dari Brahman maka umat manusia hendaknya mencari kebenaran Tuhan itu dengan berbagai macam upaya, sehingga di dapatkan pandangan dan kesimpulan yang benar. Pemahaman yang benar dan holistic tentang Tuhan, maka 
satu-satunya cara yang paling benar adalah mempelajari kitab-kitab suci dan susastra-susastra Hindu lainnya. Pernyataan itu secara tegas tersurat dalam kitab Brahma Sutra I.1.3 yang menyatakan; "Śāstrayonitvāt" yang terjemahannya adalah “ hanya kitab suci sajalah jalan menuju kepada pengetahuan yang benar dalam hubungannya dengan Brahman" (Vireśvarānanda, 2004: 74).

Terkait dengan usaha mencari hakikat Tuhan melalui pendalaman ajaran agama melalui kitab suci, dalam hal ini adalah melalui lontar, hal yang hendaknya dijadikan sebagai pedoman dan landasan pijakan kita adalah Darsana. Darsana adalah sistem filsafat India, yang berisikan tentang cara pandang yang tepat untuk menghayati Veda. Darsana sebagai sebuah sistem filsafat dapat dijadikan sebagai sebuah metode untuk memahami kitab suci dalam rangka usaha menghayati keberadaan Tuhan. Darsana dikatakan sebagai sebuah metode, karena dalam Darsana inilah dijabarkan mengenai tata cara mencari hakikat kebenaran itu, yang secara umum didasarkan pada metode Tri Pramana. Tri Pramana adalah tiga cara untuk mencari hakikat kebenaran itu baik melalui pengamatan langsung (Pratyaksa Pramana), melalui penalaran/logika (Anumana Pramana) dan melalui pendalaman ajaran dalam kitab suci (Agama Pramana). Darsana sebagai sebuah sistem filsafat terdiri dari sembilan sistem filsafat yang dikenal dengan Nava Darsana, akan tetapi yang relevan digunakan untuk menghayati ajaran Veda adalah Sad Darsana yang disebut sebagai filsafat Astika, karena meyakini kebenaran dan otoritas Veda. Filsafat dalam Darsana berbeda dengan filsafat Barat, karena sistem filsafat Darsana adalah sistem filsafat ketuhanan, sehingga tidak menisbikan atau tidak meniadakan Tuhan, bukan sekadar menggali kebenaran berdasarakan kebebesan berpikir manusia yang terbatas. Darsana adalah menggali ajaran ketuhanan sebenar-benarnya sehingga Darsana adalah cikal bakal ilmu teologi Hindu (Brahma Widya) itu sendiri.

Lontar Siwa Dharma sebagai salah satu lontar yang berjenis Tattwa di Bali, memiliki peranannya tersendiri dalam memperkokoh keyakinan umat. Akan tetapi sangat disayangkan umat Hindu belum sepenuhnya mengetahui keberadaan dan isi dalam lontar ini. Lontar jenis Tattwa ini dikenal juga dengan istilah lontar jenis Tutur. Lontar jenis ini banyak mengandung ajaran teologis, yang sejatinya pada awalnya bersumber dari perenungan-perenungan filsafat ketuhanan (Darsana). Tattwa yang ada di Bali adalah penjabaran dari ajaran darsana, sehingga pembahasan dan pelaksanaan dari ajaran Tattwa nampaknya berbeda dengan yang tersurat dalam teks-teks Sruti. Hal ini yang sering disalah tafsirkan oleh beberapa orang yang menganggap lontar dan tradisi ritual Hindu itu menentang Weda. Akan tetapi Lontar adalah pelaksanaan sistem filsafat darsana untuk melaksanakan ajaran Teologi Hindu.

Hal itulah yang mendasari penulis untuk menggunakan lontar ini sebagai bahan bahasan untuk menggali nilai-nilai Filsafat Timur yang dicerminkan pada konsep ajaran yang terkandung dalam lontar ini. Terkait dengan hal itu maka dipandang perlu untuk melakukan studi kepustakaan dan penelitian mengenai korelasi 
ajaran Darsana dalam teks Hindu di Bali yang termuat dalam Lontar Siwa Dharma. Penelitian ini penting dilakukan untuk menyelaraskan persepsi umat, sehingga tidak berpikiran sempit, menolak kemajuan berpikir umat manusia dan cenderung berpegang teguh pada pemahaman yang keliru, yang berkedok konsep mula keto.

\section{Pembahasan}

\subsection{Gambaran Umum Lontar Siwa Dharma}

Lontar Siwa Dharma adalah salah satu jenis pustaka keagaman Hindu yang ada di Bali. Lontar Siwa Dharma berdasarkan isinya digolongkan lontar jenis tutur, karena berdasarkan isinya berisi tentang ajaran-ajaran Ketuhanan, ajaran-ajaran filosofis dan teologis, yang berhubungan dengan pendalaman ajaran agama. Selain itu, lontar ini juga mengandung ajaran tentang konsep yajña yang di dalamnya berisi materi upacara/ ritual keagamaan sehingga lontar ini juga digolongkan ke dalam lontar jenis Kalpa/ Kanda.

Lontar Siwa Dharma yang dijadikan acuan dalam penelitian ini adalah transliterasi lontar milik Kantor Pusat Dokumentasi Budaya Bali, yang disalin oleh I KN Sulibra pada tanggal 14 September 1994. Secara morfologis teks Siwa Dharma ini ditulis di atas daun lontar yang berukuran panjang $40 \mathrm{~cm}$ dan lebar $3,5 \mathrm{~cm}$, yang terdiri dari sembilan (9) lembar lontar. Teks singkat ini menyajikan materinya dengan konsep prosa deskriptif, dengan menggunakan Bahasa Kawi dan Bahasa Bali Kuna sebagai bahasa pengantar dalam teks ini.
Secara umum struktur penulisan teks Siwa Dharma ini terdiri dari tiga bagian yakni Manggala, Padartha, dan Panyineb/Wasananing Wacana. Pada bagian Manggala yaitu kalimat yang mengawali penulisan teks ini adalah berupa mantra yaitu "Ong Āwighamāstu nama śidham. Pangakșama ning nghulun ring parā bhațārā. Puniki indik gama Śiwā Dharmmā, sane sampun kapatut antuk iddhā sulinggih....". Berdasarkan kutipan manggala dari teks tersebut maka dapat dipahami sebagai kalimat awal yang membuka pembicaraan dalam teks ini adalah diawali dengan puja mantra singkat (sutra mantra) dan permohonan maklum (pangaksama) dan perkenalan judul dari teks ini.

Pada bagian Padartha yang merupakan isi dari teks ini berisi tentang asal mula kedudukan Catur Wangsa dan fungsinya di masyarakat, dilanjutkan dengan konsep kosmologi (masa penciptaan dan penghancuran alam semesta), konsep ritus/ritual khususnya yang berkaitan dengan Pitra Yajña, dan konsep etika khususnya pada konsep Tri Kaya Parisudha sebagai landasan moral dalam berbuat. Konsep etika yang juga dijelaskan pada bagian akhir teks ini adalah Sad Gunna sebagai landasan etika berbuat untuk menuju kesempurnaan hidup.

Sedangkan pada bagian Panyineb atau bagian penutup adalah berisi ucapan maaf dan penyimpulan. Pada bagian akhir juga diisi tarikh penulisan teks, penulis dan tempat penulisan teks ini. Bagian inilah yang digunakan sebagai pertanda untuk menentukan kapan dibuatnya teks ini. Teks ini merupakan teks salinan, yang mana sumber aslinya tidak diketahui dari mana sumbernya. 


\subsection{Konsep Ketuhanan dalam Teks Siwa Dharma}

Konsep teologis adalah konsep Ketuhanan yang terkandung dalam teks ini. Konsep Ketuhanan yang dimaksud dalam teks ini adalah ajaran mengenai doktrin-doktrin tentang Tuhan yang menjelaskan tentang kebenaran-kebenaran ajaran Agama Hindu yang menggambarkan keimanan dan keyakinan (Sradha dan Bhakti) umat. Adapun konsep-konsep Ketuhanan yang terkandung dalam teks ini meliputi konsep Siwa Sidhanta, di mana dinyatakan Dewa Siwa sebagai dewa tertinggi yang disebut dengan Bhatara Guru, seperti yang dinyatakan dalam teks berikut ini:

....bwat kawentěnan jagat puniki, sagamā carā sang catūr wangśa. Sadaging anda bwanā punikā, wantah mtu sakeng bhațāra gurū, sang nginucap bhațārā Iśwara,tutur Wrspati Tattva, Sidājnāna, tastrā, gamā punikā, wtu saking pawarah bhațārā Śiwā, 3, kaulatang ring śastrā șașaṇa, Śiwā gammā, mwang Buddha gammā..."(Siwa Dharma 2a)

Terjemahan:

...tentang keberadaan dunia ini, melaksanakan tradisi keagamaan bagi catur wangsa. Seisi dunia ini, adalah muncul dari Bhatara Guru, yang memunculkan Bhatara Iswara, dengan tutur Wrspati Tattva, Sidājnāna, tastrā, sebagai dasar agama itu, semua muncul dari ajaran Bhatara Siwa, 3, diwujudkan dalam sastra dan etika, yang disebut Siwā gammā dan Buddha Gamma...(Penulis, 2016).
Berdasarakan teks tersebut, dapat diketahui Bhatara Siwa adalah awal dari segala ciptaan dan segala macam ajaran. Dewa Siwa dinyatakan sebagai awal mula dunia dan segala ajaran sehingga dalam Hindu kita kenal sebagai Sang Hyang Sangkan Paraning Sarat, yaitu gelar Ida Sang Hyang Widhi sebagai asal mula dan sumber dari segala yang ada di dunia ini.

Konsep Ketuhanan yang kedua adalah konsep Catur Varna sebagai pelaksana dan penjaga ajaran Siwa Sidhanta yang diturunkan oleh Dewa Siwa kepada umat manusia, seperti yang dijelaskan pada petikan sloka di bawah ini;

....makadi saking kawijilan, sang catur wangsā, lwir ipun kang ksatriyā, brahmāna, wesya, śudra, sami makawitan ring bhațārā brahmā, awinan kapāruṇdag wangsa punika rauhing basa bagsittha, punika reh nganutang kawijilane saking bhatara brahma. Sang Brahmanna mijil saking mukā, bhatara Brahma, Sang ksatriya mijil saking bahu bhatara Brahma, Wesya mijil șaking pupu bhatara brahma, sudra saking tlapakan kuku bhatara brahma....(Siwa Dharma 2b-3a)

Terjemahan:

...seperti inilah kemunculannya, Sang Catur Wangsa, diantaranya adalah ksatria, brahmana, wesya dan sudra, semua bersumber dari Bhatara Brahma, karenanya harus diatur tata bahasanya, itu disesuaikan dengan kemunculannya dari Bhatara Brahma. Sang Brahmana lahir 
dari wajah Bhatara Brahma, Sang Ksatriya muncul dari bahu Bhatara Brahma, Wesya muncul dari paha bhatara brahma, sudra berasal dari telapak kaki bhatara brahma... (peneliti, 2016)

Berdasarkan petikan teks tersebut dapat diketahui bahwa Sang Catur Wangsa hadir diciptakan oleh Bhatara Brahma untuk mengajegkan agama, karena kedudukan mereka yang muncul dari tubuh Dewa Brahma, sehingga mereka memiliki kewajiban yang sama dalam melaksanakan ajaran agama itu sendiri, dalam hal ini adalah melanjutkan ajaran ke-Siwaan itu.

Adapun yang disebut dengan ajaran ke-Siwaan dalam teks Siwa Dharma ini adalah ajaran yang diturunkan oleh Ida Sang Hyang Widhi, yang digunakan untuk mengukuhkan keyakinan dalam segala perbuatan untuk memuja keagungan Dewa Siwa. Sebagai pelaksana dalam ajaran Siwa Dharma itu adalah Sang Catur Wangsa yang kini ada di Bali. Yang disebut sebagai Agama adalah segala perbuatan yang baik dan benar, “....sane mawasta Agama, silā rahayū..."(Siwa Dharma, 4a-4b). Dengan melaksanakan perbuatan yang baik merupakan tanda kita telah melaksanakan ajaran ke-Siwa-an itu sendiri.

\subsection{Ajaran Mimamsa Darsana pada Lontar Siwa Dharma}

Mimamsa Darsana adalah salah satu sistem filsafat yang tergolong dalam kelompok Astika yaitu sitem filsafat yang mengakui kebenaran dan otoritas Weda. Mimasa berarti menganalisa dan memahami seluruhnya (Tim Penyusun, 2014: 147). Bagi Rsi Jaimini, kitab suci Veda secara praktis hanya Tuhan semata, dan Veda yang abadi tersebut tidak memerlukan dasar apapun untuk sandarannya (Tim Penyusun, 2014:168).

Pokok pembicaraan di dalam Mimamsa ialah peneguhan kewibawaan kitab Weda dan pembuktian bahwa kitab Weda membicarakan upacara-upacara keagamaan. Oleh karena itu Mimamsa juga disebut Karma-Mimamsa. Pada zaman Brahmana sudah dimulai adanya pembicaraan-pembicaraan tentang bermacammacam hal yang mengenai upacara-upacara keagamaan, dan bahwa hasil dari pembicaraanpembicaraan itu lalu disusun secara sistematis, yang kemudian menimbulkan kesusateraan yang disebut Kalpa-Sutra.

Ajaran Mimamsa dapat disebut pluralistis dan realistis, artinya: Aliran ini menerima adanya kejamakkan jiwa dan pergandaan asas bendani yang menyelami alam semesta ini, serta mengakui bahwa obyek-obyek pengamatan adalah nyata.

Sendi utama teori pengetahuan Mimamsa adalah pemahaman tentang keabsahan diri pengetahuan. tidak seperti teori pengetahuan lain yang mempertahankan bahwa klaim-klaim pengetahuan diketahui sebagai yang benar ketika mereka berhubungan dengan realitas, atau ketika mereka menuntun orang kepada tindakan yang berhasil, atau ketika mereka berpadu dalam satu sistem yang konsisten. Mimamsa menekankan bahwa kodrat pengetahuan itulah yang memberi kesaksian terhadap dirinya sendiri. Keyakinan kita akan 
kebenaran klaim yang ditunjuk pengetahuan dari kodratnya muncul sebagi satu sosok pengetahuan itu sendiri.

Mengenai alat atau cara untuk mendapatkan pengetahuan Prabhakara mengajarkan lima cara, sedangkan Kumarila Bhata mengajarkan enam cara termasuk yang diajarkan oleh Prabhakara. Keenam cara itu ialah:

1. Pengamatan (Pratyaksa)

2. Penyimpulan (anumata)

3. Kesaksian (Sabda)

4. Perbandingan (Upamana)

5. Persangkaan (Arthapatti)

6. Ketiadaan (Anupalabdi)

Empat bagian di atas sama dengan apa yang diterangkan dalam filsafat Nyaya. Bila keempat cara pertama tidak dapat dipakai untuk mendapatkan pengetahuan (kebenaran) dari suattu peristiwa, maka akanlah dipakailah cara persangkaan. Walaupun disadari bahwa cara ini perlu dibantu dengan cara lain untuk memperoleh cara yang pasti.

Bila terlihat seseorang dalam keadaan senyum dan mukanya berseri-seri, maka dapat diduga bahwa orang tersebut mendapat sukses dalam usahanya.

Kemudian Ketidak adaan (Anupalabdhi) termasuk cara yang diajarkan oleh Kumarila Bhata dan tidak termasuk diantara cara dari Prabhakara. Ketidakadaan ini dapat diterangkan dengan suatu contoh, misalnya: bila seseorang masuk dan mengamati sekeliling kamar dan mengatakan tidak ada meja di dalam kamar. Dia tidak melihat meja karena memang tidak ada meja di dalam kamar itu. Jadi orang memiliki pengetahuan dalam hal ini karena ketidakadaan (anupalabdhi) dan ketidakadaan itu memang tidak dapat diamati.

Di antara cara-cara tersebut di depan maka Mimamsa memandang bahwa cara kesaksian (sabda) yang paling penting dan utama. Karna kesaksian adalah pengetahuan yang berasal dari kata-kata atau kalimat-kalimat. Namun sebagai satu sarana pengetahuan yang sah, kesaksian menunjuk hanya pada klaim-klam verbal yang berasal dari sumber yang dapat dipercayai dan dimengerti secara benar.

Dalam hal ini adalah kesaksian kitab weda. Wedalah kebenaran yang tertinggi dan Weda pula sumber pengetahuan yang sempurna. Tidak seperti beberapa sistem yang lain, Mimamsa tidak percaya akan satu pencipta dunia atau satu pengarang ilahi kitab Weda. Sebaliknya, Weda merupakan perwahyuan langsung dan kekal dari realitas itu sendiri.

Kesetian atau kejujuran yang mendasari keyakinan keagamaan Veda terdiri atas bermacammacam unsur, yaitu:

1. Percaya dengan adanya roh yang menyelamatkan dari kematian dan mengamati hasil ritual di surga.

2. Percaya tentang adanya kekuatan atau potensi yang melestaikan dampak dari ritual yang dilaksanakan. 
3. Percaya bahwa hidup di dunia adalah suatu kenyataan dan semua tindakan yang kita lakukan dalam hidup ini bukanlah suatu bentuk ilusi.

Berdasarkan konsep tersebut dapat dipahami bahwa inti ajaran Mimasa Darsana adalah pelaksanaa dari Ajaran yajna sebagai media untuk meneguhkan keyakinan umat manusia kepada keberadaan Atma dan sumber dari Atma itu sendiri yakni Ida Sang Hyang Widhi Wasa. Yajña digunakan sebagai media penyucian yang harus dilalui oleh umat manusia, sehingga dapat meningkatkan kualitas hidup manusia. Pelaksanaan yajña didasarkan pada pemikiran bahwa inti ajaran Veda yang murni adalah pelaksanaan upacara kurban untuk melunasi hutang (Tri Rna) sehingga dapat menebus segala kekotoran dan ketidaksucian diri.

Lontar Siwa Dharma sangat jelas menekankan bahwa keberadaan umat manusia lahir ke dunia agar dapat menuju kesadaran keSiwaan itu satu-satunya cara adalah dengan melaksanakan upacara Yadnya. Upacara Yadnya dijadikan sebagai media penyucian (samskara) sekaligus sebagai media penstanaan kekuatan Tuhan dalam diri manusia itu sendiri. Konsep pelaksanaan Yadnya dalam teks Siwa Dharma ini sangat sesuai dengan inti ajaran Mimamsa yang menekankan pada pelaksanaan ritual yadnya sebagai landasan mengakui dan mengimani kebenaran otoritas Weda tersebut.

Pernyataan dalam teks Siwa Dharma dengan tegas menyatakan bahwa pelaksanaan
Yadnya harus dilakukan oleh Sang Catur Wangsa, terlebih-lebih pelaksanaan yadnya yang berhubungan dengan usaha penyucian diri. Upacara yang terkait dengan upacara penyucian diri tersebut meliputi tiga upacara yaitu Pitra Yadnya, Manusa Yadnya, dan Bhuta Yadnya.

Pitra Yadnya adalah persembahan yang dilandasi kesuciam yang dihaturkan kehadapan Pitara dan Pitari (leluhur), sebagai bentuk rasa hormat dan bhakti kepada leluhur (Subagiasta,2008: 5). Berdasarakan pengertian konseptual tentang pelaksanaan Pitra Yadnya ini maka pelaksnaan pitra yadnya dalam teks ini lebih cenderung pada upacara Antyesti Sradha dengan menggunakan sarana penyucian berupa tirtha dan api. Tirtha yang digunakan adalah Tirta Pangentas, Tirta Pamanah dan Tirtha Panembak.

Penggunaan ketiga tirtha sebagai sarana penyucian ini sangat terkait dengan tujuan dari Antyesti Sradha, yang memanfaatkan sarana air suci sebagai media penyucian yang utama. Hendaknya perlu dipahami bahwa penggunaan ketiga tirtha ini memang memiliki peranan yang sangat penting dalam upacara Pitra yadnya khususnya upacara Pangabenan yang ada di Bali.

Selain penggunaan ketiga tirta, unsur utama dalam upacara penyucian sang Hyang Atma adalah dengan cara Kageseng yaitu diperabukan dengan sarana api. Api adalah sarana penyucian yang utama dalam upacara Pitra Yadnya ini, yang merupakan media untuk mempercepat kembalinya unsur-unsur Panca Maha Bhuta dalam tubuh manusia kembali pada unsurnya di Bhuana Agung (alam semesta). Api yang digunakan ini disebut sebagai Citta Gni, yaitu api pembakaran jenazah 
yang dapat mengembalikan unsur-unsur Panca Maha Bhuta sehingga menjadi suci kembali. Teks Siwa Dharma ini dengan tegas menyatakan bahwa api yang digunakan untuk memperabukan jenazah Catur Wangsa ini merupakan sarana penyucian yang utama, sehingga bisa terbebas dari kurungan badan yang membelengu ini. Cittagni sangat penting disediakan dalam upacara Pitra Yadnya untuk menyucikan unsur Stula Sarira.

Teks Siwa Dharma pada pernyataan berikutnya juga menyatakan bahwa tujuan utama pelaksanaan yadnya ini adalah membuat bahagia para leluhur. Hal itu sangat sesuai dengan prinsip dasar pemikiran Mimamsa Darsana pada poin pertama pada inti ajaran Mimamsa. Veda menghendaki adanya peningkatan kesucian diri manusia dengan melakukan pemujaan-pemujaan pada Tuhan, melalui ritual-ritual suci yang disebut yadnya.

Konsep ritualisme yang terkait dengan konsep ajaran Mimamsa Darsana adalah pelaksanaan Bhuta Yadnya yaitu persembahan atau pengorbanan yang tulus ikhlas yang ditujukan kehadapan para makhluk bawahan atau para bhuta kala (Subagiasta, 2008: 7). Dalam teks-teks Kalpa Sutra yang menjadi acuan dalam pelaksanaan sistem filsafat Mimamsa Darsana ini, bahwasannya pelaksanaan Bhuta Yadnya yang disbut dengan Balikrama perlu dilakukan untuk menyucikan alam semesta sehingga mampu mewujudkan keseimbangan alam dan keharmonisan antara Bhuana Agung dan Bhuana Alit.

Hendaknya pelaksanaan Bhuta Yadnya yang berupa Caru dan Tawur harus secara periodic dilakukan oleh umat manusia dalam hal ini adalah para Catur Wangsa untuk memelihara khidupan dan kelangsungan hidupnya. Pelaksanaan upacara Caru dan Tawur dalam teks Siwa Dharma ini adalah sebagai wujud penyucian alam semesta. Penyucian alam semeta perlu dilakukan untuk menetralisir pengaruh-pengaruh buruk dari alam sehingga mampu mewujudkan keseimbangan dan keharmonisan alam. Keseimbangan dan keharmonisan alam itu merupakan prasarat untuk mewujudkan Bhutahita dan Atmahita. Konsep Bhutahita dalam teks Siwa Dharma ini aalah kebahagian alam semesta dan juga isinya, sedangakan Atmahita adalah mewujudkan kebahagian dalam diri manusia itu sendiri.

Terwujudnya Bhutahita dan Atmahita ini akan memberikan keseimbangan alam semesta yang berdampak pada terwujudnya kehidupan manusia yang bahagia dan sejahtera. Karena menurut konsep Mimasa itu sendiri bahwa pelaksanaan yadnya pada hakikatnya adalah mensejahterakan hidup manusia. Upaya mensejahterakan hidup itu dilakukan dengan mewujudkan bhuta hita dan atma hita tersebut.

\subsection{Ajaran Yoga Darsana dalam Lontar Siwa Dharma}

Ajaran Yoga Darsana pada teks ini memang tidak dijelaskan secara eksplisit melalui untaianuntaian padartha dalam teks Siwa Dharma ini. Ajaran Yoga Darsana ini tercermin secara implicit dari konsep-konsep etika/ susila dalam teks Siwa Dharma ini. Unsur implicit ini dapat ditelaah melalui pernyataan-pernyataan dalam teks ini yang mengusahakan berbagai macam ritual dan 
pelaksanaan ajaran kesusilaan itu digunakan untuk mempersatukan Sang Atma dengan Bhatara Siwa.

Adanya upaya penyatuan diri dengan pengendalian diri melalui pelaksanaan ajaran Tri Kaya Parisudha dan Sad Gunna itu merupakan implementasi praktis dari inti ajaran Yoga Darsana yaitu "Yogas Citta Wrtti Nirodhhah" yang bermakna pengendalian gerak-gerak pikiran yang bebas. Pengendalian gerak pikiran ini adalah upaya untuk mengendalikan gerak perilaku dan aktivitas manusia.

Pelaksanaan upacara yadnya juga sejatinya adalah sebuah upaya pengendalian dalam hal ini adalah mengendalikan pikiran dan perilaku. Dalam teks Siwa Dharma ini dinyatakan bahwa hendaknya segala ritual itu dilaksanakan dengan penuh kehati-hatian. Sikap berhati-hati ini merupakan sebuah upaya nyata pengendalian diri, sehingga mampu mewujudkan sikap yang terjaga dan terkendali.

Yadnya adalah Yoga yang dipraktekkan dalam kegiatan nyata manusia dalam kehidupan seharihari. Teks Siwa Dharma menyatakan bahwa yadnya memperhalus budhi manusia sehingga mampu mencapai ketenangan diri yang disebut sebagai Santa yaitu keseimbangan jiwa dan raga untuk mampu menghayati alam ke-Siwaan itu.

\section{Penutup}

Berdasarkan pembahasan di atas, maka dapat disimpulkan hal-hal berikut ini adalah Lontar Siwa Dharma merupakan lontar yang bermazabkan Siwaisme, yang mengandung ajaran
Siwa Sidhhanta dengan mewujudkan kesadaran diri manusia melalui pelaksanaan ajaran keSiwaan tersebut. teks ini berisi tentang asal mula kedudukan Catur Wangsa dan fungsinya di masyarakat, dilanjutkan dengan konsep kosmologi (masa penciptaan dan penghancuran alam semesta), konsep ritus/ritual khususnya yang berkaitan dengan Pitra Yajña, dan konsep etika khususnya pada konsep Tri Kaya Parisudha sebagai landasan moral dalam berbuat. Konsep etika yang juga dijelaskan pada bagian akhir teks ini adalah Sad Gunnna sebagai landasan etika berbuat untuk menuju kesempurnaan hidup.

Konsep ajaran Filsafat (India) Hindu yang tercermin dalam teks Siwa Dharma ini adalah sebagai berikut, 1) Mencerminkan ajaran Mimamsa Darsana karena teks ini menjadikan upacara yadnya sebagai upaya pemujaan kepada Tuhan sekaligus upaya meningkatkan kesucian diri, 2) Teks ini mencerminkan sistem filsafat Yoga Darsana karena terkait dengan upaya pengendalian diri dan gerak pikiran melalui sistem etika yang terkandung pada teks Siwa Dharama yaitu yang dicerminkan dalam ajaran Tri Kaya Parisuddha dan Sad Gunna.

\section{DAFTAR PUSTAKA}

Darmayasa. 2014. Bhagavad-gìtā (Nyanyian Tuhan). Denpasar: Yayasan Dharma Sthapanam.

Donder, I Ketut. 2006. Brahmavidyā: Teologi Kasih Semesta dan Kritik Terhadap Epistemologi Teologi, Klaim Kebenaran, 
Program Misi, Komparasi Teologi, dan Konversi. Surabaya: Pāramita.

Simpen, I Wayan. 1982. Kamus Bahasa Kawi

Indonesia. Denpasar: Mabhakti Offset.

Subagiasta, I Ketut. 2008. Pengantar Acara

Agama Hindu. Surabaya: Paramita.

Sudirga, Ida Bagus dan I Nyoman Yoga Segara.

2014. Pendidikan Agama Hindu dan Budi

Pekerti Kelas X. Jakarta: Kementerian

Pendidikan dan Kebudayaan RI.

Sulibra, I KN. 1994. Transliterasi Lontar Siwa

Dharma. Denpasar: Pusat Dokumentasi

Budaya Provinsi Bali

Surada, I Made. 2007. Kamus SansekertaIndonesia. Surabaya: Pāramita.

Vireśvarānanda, Svami. 2004. Brahma Sutra. Surabaya: Pāramita.

Watra, I Wayan. 2007. Pengantar Filsafat Hindu (Tattwa I). Surabaya: Pāramita. 